\title{
The Nicotinic Receptor of Cochlear Hair Cells: A Possible Pharmacotherapeutic Target?
}

\author{
Ana Belén Elgoyhen ${ }^{a, b},{ }^{*}$, Eleonora Katz ${ }^{a, c}$, and Paul A. Fuchs ${ }^{d}$ \\ alnstituto de Investigaciones en Ingeniería Genética y Biología Molecular, Consejo Nacional de \\ Investigaciones Científicas y Técnicas, Buenos Aires 1428, Argentina \\ bepartamento de Farmacología, Facultad de Medicina, Universidad de Buenos Aires, Buenos \\ Aires 1121, Argentina \\ 'Departamento de Fisiología, Biología Molecular y Celular, Facultad de Ciencias Exactas y \\ Naturales, Universidad de Buenos Aires, Buenos Aires 1428, Argentina
}

${ }^{\mathrm{d} D e p a r t m e n t}$ of Otolaryngology, Head and Neck Surgery, the Center for Hearing and Balance, and the Center for Sensory Biology, The Johns Hopkins University School of Medicine, Baltimore, MD 21205-2195, USA

\begin{abstract}
Mechanosensory hair cells of the organ of Corti transmit information regarding sound to the central nervous system by way of peripheral afferent neurons. In return, the central nervous system provides feedback and modulates the afferent stream of information through efferent neurons. The medial olivocochlear efferent system makes direct synaptic contacts with outer hair cells and inhibits amplification brought about by the active mechanical process inherent to these cells. This feedback system offers the potential to improve the detection of signals in background noise, to selectively attend to particular signals, and to protect the periphery from damage caused by overly loud sounds. Acetylcholine released at the synapse between efferent terminals and outer hair cells activates a peculiar nicotinic cholinergic receptor subtype, the $\alpha 9 \alpha 10$ receptor. At present no pharmacotherapeutic approaches have been designed that target this cholinergic receptor to treat pathologies of the auditory system. The potential use of $\alpha 9 \alpha 10$ selective drugs in conditions such as noise-induced hearing loss, tinnitus and auditory processing disorders is discussed.
\end{abstract}

\section{Keywords}

nicotinic cholinergic receptors; noise trauma; cochlea; tinnitus; efferent feedback

\section{Introduction}

Sensory systems perform a series of common functions. Each system responds with some specificity to a stimulus from the surrounding world and employs some specialized receptor cells at the periphery to translate those stimuli into electrical signals that all neurons can

\footnotetext{
*Corresponding author at: Instituto de Investigaciones en Ingeniería Genética y Biología Molecular (INGEBI-CONICET), Vuelta de Obligado 2490, 1428 Buenos Aires, Argentina; e-mail: elgoyhen@dna.uba.ar; phone: xx 541147832871 ; fax: xx 541147868578.

Publisher's Disclaimer: This is a PDF file of an unedited manuscript that has been accepted for publication. As a service to our customers we are providing this early version of the manuscript. The manuscript will undergo copyediting, typesetting, and review of the resulting proof before it is published in its final citable form. Please note that during the production process errors may be discovered which could affect the content, and all legal disclaimers that apply to the journal pertain.
} 
understand. That initial electrical event begins the process by which the central nervous system constructs an orderly representation of for example, sounds, odors, tastes and visual objects. Thus, basic sound detection begins when sound waves strike the eardrum, which transmits that physical stimulus to the organ of Corti within the cochlea, the sensory epithelium of the mammalian inner ear. Here the primary receptor cells transform mechanical input into electrical signals that are sent to the central nervous system by the auditory nerve [1]. However, unlike vision, touch and the chemical senses, sound transduction is modulated by efferent signals (olivocochlear, OC) that travel in reverse, from the brain back to the inner ear [2]. The present work reviews the data which demonstrates that synaptic transmission between medial OC (MOC) fibers and cochlear hair cells is mediated by a peculiar nicotinic cholinergic receptor (nAChR), the $\alpha 9 \alpha 10$ receptor. In addition, we discuss possible pharmacological targeting of this receptor in inner ear pathologies, as well as in auditory processing disorders and reading disabilities.

\section{Organization of the mammalian cochlea}

There are approximately 16,000 sensory hair cells in the human cochlea. They are organized in a tonotopic fashion, with those sensitive to high frequency sound at the basal end and those sensitive to low frequency at the apical end of the cochlear coil [1]. Hair cells are neuroepithelial cells, with the apical pole specialized for mechanotransduction and the basal pole specialized for the release of neurotransmitter. The mammalian cochlea contains two classes of hair cells arranged in rows along the organ of Corti. Inner hair cells (IHCs), of which there are approximately 3,500 in each human cochlea, are innervated by dendrites of the auditory nerve and are considered to be the primary sensory hair cells of the cochlea. Outer hair cells (OHCs) number approximately 11,000 in each human cochlea and lie in 3 rows. They have a much less pronounced afferent innervation, but are the target of an efferent neural pathway [2-5]. IHCs are also a target for a descending pathway, but in this case, the efferent axons form a synapse on the postsynaptic (afferent) terminal and will not be considered further here.

\section{Amplification in the mammalian ear}

The receptor cells of most sensory organs must amplify their signals in order to separate them from background noise. Photoreceptors, for example, use a biochemical cascade to enhance their responses several thousand-fold after transduction has been accomplished. Cochlear hair cells, instead use an active mechanical process to amplify their inputs [6,7]. When sound reaches the cochlea, it elicits mechanical vibrations that are sensed and transduced into an electrical response by motion of the hair bundles of hair cells which contain the mechanicallygated ion channels. At the same time, however, the hair cells perform work by increasing the magnitude of their mechanical input. This amplification of the stimulus constitutes a positive feedback that enhances the sensitivity of hearing by countering the loss of energy through the viscous dissipation that accompanies the motion of hair bundles and other structures through the fluids of the inner ear.

There is little debate that in mammals OHCs are the principal players providing the feedback that drives cochlear amplification. Two alternative mechanisms for amplification have been described. One in which amplification results from a nonlinearity in the transduction mechanism itself [8-10] and another in which the hair cell receptor potential drives a novel motile process within the lateral membrane of the OHC soma [11]. In this scenario, hyperpolarization causes the cell to expand along its longitudinal axis and depolarization causes it to contract. Somatic electromotility of $\mathrm{OHCs}$, as the basis for cochlear amplification, is a mammalian novelty and is mediated by the motor-protein prestin [12], a member of the solute carrier anion-transport family 26 (SLC26) that has undergone Darwinian selection only in the 
mammalian lineage [13,14]. The contribution of transduction nonlinearity to amplification in the mammalian cochlea is still a matter of debate.

\section{Amplification is under the control of the medial olivocochlear system}

The MOC efferents (Figure 1A) originate in the medial portion of the superior olivary complex and project to of the organ of Corti, where they form large synaptic contacts with OHCs (Figure $1 \mathrm{~A}$ and B) [2]. Activation of the MOC pathway reduces cochlear sensitivity and tuning in a frequency selective manner, by inhibiting the mechanical amplification of low-level sounds that occurs before the sound stimulates the IHCs and the auditory nerve fibers [2, 15].

Olivocochlear efferent neurons permit the central nervous system to control the way that sounds are processed in the auditory periphery, offering the potential to improve the detection of signals in background noise [16-18], to selectively attend to particular signals [19,20], and to protect the periphery from damage caused by overly loud sounds [21-25].

\section{The nicotinic cholinergic receptor of cochlear hair cells}

Acetylcholine (ACh) is the principal neurotransmitter released by MOC terminals. While both muscarinic and nicotinic receptors have been proposed to mediate the effects of $\mathrm{ACh}$ in the cochlea, pharmacological and electrophysiological data suggest a central role for an atypical, nAChR located at the synapse between efferent fibers and OHCs [15,26-34]. Current data indicates that activation of the hair cell $\mathrm{nAChR}$ leads to an increase in intracellular $\mathrm{Ca}^{2+}$ and the subsequent opening of small conductance $\mathrm{Ca}^{2+}$-activated $\mathrm{K}^{+}$(SK2) channels, thus leading to hyperpolarization of hair cells (Figure 2) and reduction of electromotility [33-36].

The cloning of the $\alpha 9$ nicotinic cholinergic receptor subunit deciphered the ionotropic molecular nature of the hair cell cholinergic receptor and established its inclusion within the nicotinic family of cholinergic receptor subunits [37]. The generation of mice carrying a null mutation for the gene encoding the $\alpha 9$ subunit (Chrna9) has unequivocally demonstrated that this subunit is a main component of the native $\mathrm{OHC}$ cholinergic receptor [38]. Characterization of the rat $\alpha 9 \mathrm{nAChR}$ subunit revealed that it formed homomeric, calcium-permeable, AChgated channels when expressed in Xenopus laevis oocytes with pharmacological properties largely indistinguishable from those reported for the native hair cell cholinergic receptor [37, 39-41]. Moreover, a combination of in situ hybridization and reverse transcription-polymerase chain reaction (RT-PCR) experiments have shown $\alpha 9$ transcripts in cochlear and vestibular hair cells of several vertebrate species $[37,42,43]$.

The cloning of the $\alpha 9$ subunit added a peculiar member to the nicotinic family of receptor subunits. When expressed in Xenopus laevis oocytes, $\alpha 9$ forms a homomeric receptor-channel complex that is activated by $\mathrm{ACh}$, but displays a very distinct pharmacological profile. This matches neither the nicotinic nor the muscarinic subdivision of the pharmacological scheme of cholinergic receptors, and in addition has sensitivities in common with $\mathrm{GABA}_{\mathrm{A}}$, glycine and $5 \mathrm{HT}_{3}$ receptors [40]. Moreover, $\alpha 9$ is a distant member of the $\mathrm{nAChR}$ family with an amino acid sequence identity compared to all known nicotinic subunits (other than $\alpha 10$ ) of less than $39 \%$. This, taken together with the fact that the structure of the gene that encodes the $\alpha 9 \mathrm{nAChR}$ (Chrna9) subunit differs from that of all known genes coding for nAChR subunits [26,29,37, 44], indicates that $\alpha 9$ represents an early divergent branch closer to the ancestor that gave rise to the nicotinic gene family $[45,46]$.

With the cloning of $\alpha 9$, the working hypothesis was that the $\alpha 9$ nicotinic subunit, functioning as a homopentameric acetylcholine-gated channel, was the native hair cell cholinergic receptor. However, three properties of homomeric $\alpha 9$ receptors properties did not match those seen in isolated hair cells: the current-voltage relationship, the $\mathrm{Ca}^{2+}$ sensitivity and the desensitization kinetics $[26,29,44]$. The cloning of the $\alpha 10 \mathrm{nAChR}$ from cochlear libraries and the expression 
of both $\alpha 9$ and $\alpha 10$ in Xenopus laevis oocytes demonstrated that the $\alpha 9 \alpha 10$ receptor thoroughly recapitulates the pharmacological and biophysical properties of hair cell nAChR [47-49]. Moreover, the generation of Chrnal0 null mutant mice has indicated that, while functional homomeric $\alpha 9$ channels are present in OHCs of these genetically modified mice, they are insufficient to drive normal MOC efferent inhibition to the cochlea, demonstrating that the $\alpha 10$ subunit is also an essential component of the hair cell nAChR [50]. Thus, it is now believed that the hair cell cholinergic receptor that mediates synaptic transmission between efferent OC fibers and hair cells of the cochlea, is formed by both $\alpha 9$ and $\alpha 10$ subunits, in a pentameric structure with a most likely $(\alpha 9)_{2}(\alpha 10)_{3}$ stoichiometry [37,47,51].

An interesting feature of the $\alpha 9$ and $\alpha 10 \mathrm{nAChR}$ subunits is their evolutionary history [14]. The introduction of a descending fiber pathway to the inner ear occurred early in evolution, predating the emergence of terrestrial life and is a common feature among all vertebrates [2]. Therefore, one would expect similar evolutionary histories of the genes coding for the $\alpha 9$ and the $\alpha 10$ subunits across all vertebrate lineages. Intriguingly, while Chrna9 has been under strong purifying pressure throughout vertebrates, Chrnalo shows signs of positive Darwinian selection only along the lineage leading to mammals [14]. This suggests that mammalian $\alpha 9 \alpha 10$ nicotinic receptors probably acquired a novel function that evolved in conjunction with properties specific to mammalian hearing. Co-varying with the evolutionary history of Chrnal0 is prestin, the protein responsible for somatic electromotility of mammalian OHCs, which has also been under positive selection pressure only in mammals [14]. Thus, it is tempting to speculate that Chrnalo has evolved to give the mammalian auditory system feedback control of prestin-driven somatic electromotility, a capacity that is not required in non-mammalian species.

\section{The $\alpha 9 \alpha 10 \mathrm{nAChR}$ and pathologies related to the auditory pathway. A target for pharmacological intervention?}

\subsection{Hearing Loss}

Millions of people the world round have hearing loss or associated conditions, such as tinnitus, otitis media and Ménières disease. According to the World Health Organization 250 million people worldwide have a moderate-to-severe or greater hearing loss (www.who.int/pbd/deafness/facts/en/index.html). This figure more than doubles if people with mild hearing loss are included. Hearing impairment is one of the most common sensory disabilities, and may drastically limit the quality of life, with an incidence of 1:1000 in newborns. It becomes increasingly prevalent with age. Hearing loss affects approximately 17 in every 1000 children under the age 18, approximately 314 in 1000 adults over age 65, and $40-50 \%$ of people 75 and older. The Royal National Institute for Deaf People, UK (www.rnid.org.uk), estimates that there are over 300 million people in the world with agerelated hearing loss and this is expected to increase to 900 million by 2050 [52]. It is the third most common chronic condition in the older population (after arthritis and high blood pressure) [52].

Hearing loss is a social and economic burden. It can cause considerable difficulties in communication with the outside world in general and lead to sadness, depression, anxiety, social isolation, and insecurity [53]. To function in a hearing society, hearing-impaired persons require specialized education, social services, and other resources. Children who are born profoundly deaf face severe difficulty acquiring spoken language and are often taught in special schools. Severe to profound hearing loss is expected to cost society $\$ 297,000$ over the lifetime of an individual. Most of these costs $(67 \%)$ are due to reduced work productivity, although the use of special education resources among children contributes an additional $21 \%$. Lifetime costs for those with prelingual onset of deafness exceed \$1 million [54]. 
Hearing loss is caused by several environmental and genetic factors and the proportion attributed to inherited causes is thought to be at least 50\% [55,56]. Progress in identifying genes involved in deafness has been remarkable over the past few years. At the end of 1996, no nonsyndromic deafness genes had been cloned. In the 12 years since then, almost 50 new genes involved in non-syndromic deafness have been identified, together with an even larger number of genes implicated in syndromic deafness [55]. Whereas single-gene defects probably account for over half of the cases of childhood deafness, the nature of the genetic contribution to progressive and age-related hearing loss has not yet been clearly defined. So far, over 100 loci involved in non-syndromic deafness have been reported (The Hereditary Hearing loss Homepage, http://webh01.ua.ac.be/hhh/) and over 400 distinct syndromes including hearing impairment are listed in Online Mendelian Inheritance in Man (http://www.ncbi.nlm.nih.gov/sites/entrez?db=omim). Thus, there are many more genes awaiting identification.

Mutations in Chrna9 and Chrnal0 associated with hearing impairment have not been identified so far. Human Chrna9 and Chrnal0 are localized to chromosomes 4p14 and 11p15.5, respectively (Ensembl, www.ensembl.org). In addition, no non-syndromic loci have been linked near the Chrna9 locus (The Hereditary Hearing loss Homepage,

http://webh01.ua.ac.be/hhh/). As reported in the The Hereditary Hearing loss Homepage (http://webh01.ua.ac.be/hhh/) a genetic linkage study conducted on a large multigenerational US family with non-syndromic autosomal dominant progressive hearing loss resulted in the localization of a deafness locus, DFNA32. The deafness gene segregating in this family was mapped to the telomere region of chromosome $11 \mathrm{p} 15$ with a maximum lod score of 4.1 with marker D11S1984 (The Hereditary Hearing loss Homepage, http://webh01.ua.ac.be/hhh/). No further studies have been performed which narrow down the locus or identify a candidate gene. This genetic marker is $2 \mathrm{cM}$ away from the Chrnalo locus, pinpointing ChrnalO as a candidate gene. However, the fact that in Chrna 9 and ChrnalO knockout mice the basal auditory function is normal $[38,50]$, might indicate that no major hearing impairment is expected from mutations which lead to loss of function of the $\alpha 9 \alpha 10 \mathrm{nAChR}$. Gene knockout experiments have the drawback that compensatory expression of other genes might obscure a clear interpretation. Alternative experiments in which the efferent system has been sectioned have indicated alterations in cochlear functioning. In an anatomical study, Pujol and Carlier [57] sectioned the $\mathrm{OC}$ bundle in neonatal cats and reported that the afferent innervation of OHCs failed to develop normally. They suggested that the normal arrival of MOC terminals at the OHCs during postnatal development is necessary to effect the pruning of exuberant afferent contacts in the $\mathrm{OHC}$ area. In a physiological study, Walsh and McGee [58] showed that transection of the OC bundle in neonatal cats eliminates the rhythmic responses normally seen in the spike trains of immature auditory neurons and suggested that the OC bundle may play a role in culling exuberant contacts between IHCs and their afferents. Both results are consistent with the idea that the OC bundle plays a role during cochlear development. Moreover, cats de-efferented shortly after birth show increased characteristic frequency-threshold, broadened tuning, and compressed spontaneous rates in adulthood [59], indicating that the OC system provides developmental influences necessary for the acquisition of normal adult cochlear function. It should be noted that during early developmental stages cholinergic OC fibers project to the IHC region where they make direct contacts with these cells [60]. The fact that the efferent synaptic activity during this developmental period is mediated through $\alpha 9 \alpha 10 \mathrm{nAChRs}$ [60-62], indicates that the developmental effects of the OC system are due to the activation of these receptors. It still remains to be established in humans whether alterations in the efferent system during early developmental periods lead to similar cochlear developmental abnormalities and if mutations in either Chrna9 and/or Chrnalo lead to hearing impairment. 


\subsection{Noise-Induced Hearing Loss}

Noise is the greatest causative factor among the defined etiologies of hearing loss. Since the industrial revolution, an increasing number of people are being exposed to extreme levels of noise. Noise at levels $85 \mathrm{dBA}$ and higher can lead both to mechanical and metabolic damage of the cochlea [63,64]. Single, repeated or continuous exposure to high levels of noise can cause Noise-Induced Hearing Loss (NIHL, Table 1). Since millions of people are daily exposed to harmful levels of noise, NIHL is one of the most important workplace hazards. Occupations such as the military [65-67], construction [68-70], mining [71], forestry [72], farming [73], aviation [74-76], rail [77,78] and trucking [79,80] report the urgent need to develop hearing conservation programs. In addition, recreational noise, like attending rock concerts or discos or the use of MP3 players, reach sound pressure levels in the dangerous zone [81,82]. The efficacy of hearing-protection devices (e.g. earplugs) and hearing-protection measures (i.e. reduced noise exposure time) could be augmented by pharmacological agents that might reduce NIHL more effectively, reducing the compensation costs associated with NIHL across all industries [83].

At present, there is no FDA-approved drug product that can reduce or prevent NIHL. However, animal work has demonstrated that different compounds acting on several biochemical pathways are effective in preventing NIHL [83]. This include agents that reduce the concentration of reactive oxygen species, reactive nitrogen species and free radicals [84], glutathione precursors [85], agents that prevent hair cell apoptosis by disrupting mitogenactivated protein kinase (MAPK) cell death signaling through peptide inhibition of c-Jun Nterminal Kinase [86], drugs like ebselen that mimic the effect of glutathione peroxidase [87] and NMDA receptor antagonists $[88,89]$. A few compounds are in the pharmaceutical pipeline, like ebselen (Phase II, Sound Pharmaceuticals) and the JNK MAPK-mediated apoptosis blocker AM-111 (Phase II, Auris Medical).

Compounds that augment the effect of the MOC system to the OHCs appear as an alternative strategy to prevent NIHL. Many studies have implicated OC feedback in protecting the cochlea from acoustic injury: electrical stimulation of the OC bundle reduces temporary threshold shifts from acoustic overexposure [90] and chronic section of the OC bundle renders the ear more vulnerable to permanent acoustic injury $[91,92]$. In mice, an assay that measures the strength of this sound-evoked OC feedback pathway to the inner ear, has shown that it is inversely correlated with the degree of hearing loss after subsequent noise [22]. That the medial branch of the OC system is involved in protection has been demonstrated in a transgenic mice that overexpress the $\alpha 9 \mathrm{nAChR}$ subunit [23]. Moreover, a knockin mouse engineered to accommodate a leucine for threonine substitution at position $9^{\prime}$ of the second transmembrane region of the $\alpha 9$ subunit, has a pronounced prolongation of efferent synaptic currents, a dramatic increase in the MOC effect as assessed by electrical stimulation of efferent axons in the floor of the IVth ventricle, and increased auditory thresholds [25]. In addition, this sole mutation renders mice more resistant to permanent NIHL. These results confirm that protection by MOC feedback depends explicitly on activation of the hair cell's $\alpha 9 \alpha 10 \mathrm{nAChR}$ and indicates that the $\mathrm{nAChR}$ itself could be modulated to provide therapeutic protection. In addition, it gives some hints concerning the properties of a possible otoprotectant drug, since in the mutant mice nAChRs have decreased desensitization kinetics plus increased agonist apparent affinity [25].

\subsection{Tinnitus}

Tinnitus (commonly referred to as ringing in the ears or head) is often one of the first signs of potential damage to hearing, especially after exposure to loud noise. One in 10 adults have clinically significant tinnitus (regular prolonged spontaneous tinnitus lasting 5 minutes or more), and for 1 in 100 tinnitus severely affects their ability to lead a normal life [93-95]. 
Estimates indicate that 13 million people in western Europe and the USA currently seek medical advice for their tinnitus [52]. Over 4 million prescriptions are written each year for tinnitus relief, but these are all for off-label drugs from a wide variety of therapeutic classes and most are associated with considerable side effects. Despite the significant unmet clinical need for a safe and effective drug targeting tinnitus relief, there is currently no FDA-approved drug on the market. The Royal National Institute for Deaf People, UK, estimates that a novel tinnitus drug could have a product value of US\$689 million in its first year of launch [52].

There are very few drugs in clinical trials for tinnitus. One that has reached Phase III is neramexane, from Merz Pharmaceuticals Gmbh (www.clinicaltrials.gov). Neramexane was developed as a follow up to memantine used for Alzheimer disease. Like memantine, neramexane was studied in individuals with moderate to severe Alzheimer disease, but it did not meet its primary endpoint efficacy measurements of SIB (Severe Impairment Battery) and ADCS-ADLsev (ADCS-ADL severe subset) when tested in Phase III trials in combination with cholinesterase inhibitors. A second Phase III trial as monotherapy showed statistical significance for neramexane in individuals with moderate to severe disease; the primary endpoint of this trial was efficacy measurement of ADCS-ADL, and further Phase III studies are under way [96]. As memantine's patent is expected to expire in 2010, neramexane may be an early follow-on product and must show a level of differentiation over memantine if it is to succeed. Nonetheless, with a number of other indications also in development for neramexane (including neuropathic pain, tinnitus and alcohol dependence), it is clear there is commitment from Merz behind it [96].

According to the information provided in the clinical trial web site (www.clinicaltrials.gov), it is proposed that neramexane may alleviate tinnitus symptoms due to its NMDA [97] and $\alpha 9 \alpha 10$ [98] nAChR blocking activities. Although early on tinnitus was considered an inner ear disorder, it is now clear that chronic tinnitus is due to neuronal abnormalities in the central nervous system [99]. Thus, it is difficult to envision how targeting a receptor expressed in the inner ear might be beneficial for chronic tinnitus. One possible explanation might result from the fact that in those patients where tinnitus is associated with hearing loss, tinnitus is alleviated when hearing impairment is reduced. This is the case for patients with hearing loss and tinnitus that have been cochlear implanted [100]. Thus, blockage of $\alpha 9 \alpha 10$ receptors could increase cochlear amplification by decreasing the activity of the MOC feedback effector system and therefore $\alpha 9 \alpha 10$ antagonists might be beneficial for the treatment of tinnitus, most likely in conjunction with some central nervous system acting drug. Possible side effects as the result of the blockade of $\alpha 9 \alpha 10 \mathrm{nAChRs}$, such as increased sensitivity to NIHL, should be taken into account.

\subsection{Auditory processing disorders}

Failure to acquire adequate reading skills (reading being slower or less accurate than expected for age) is one of the most common neurobehavioral problems affecting children. Dyslexic children have an impairment of the development of the phonetic skills necessary to identify and properly use the constituent sounds of written words, due to a temporal processing deficit that affects the sensory input needed for the proper phonological coding critically required for reading [101,102]. These deficits are aggravated in the presence of background noise, suggesting that a noisy environment, such as often prevails in the classroom, is particularly deleterious for such children $[103,104]$.

The neural mechanisms underlying speech intelligibility-in-noise have not yet been well identified, but the MOC system probably plays a role. Animal studies have shown that efferent bundle activation can improve hearing-in-noise by exerting an antimasking effect $[17,105]$. In humans, weak MOC functioning is correlated with poor tone detection in background noise [106-109] and reduced speech intelligibility-in-noise in both adults [110] and children [111]. 
Moreover, impaired MOC system functionality in learning-impaired children, in a context of multiple phonemic confusion between voiced/voiceless phonemes, has been described [112]. In addition, the MOC system has been shown to function more strongly in professional musicians $[108,113]$, suggesting the possibility that sound conditioning could strengthen these auditory descending pathways. Indeed, intensive auditory training has been shown to increase MOC activity, and to improve speech perception [114]. MOC activity measured on the first training day strongly predicts the subsequent amount of improvement, such that weaker initial MOC activity is associated with greater improvement [115]. Thus enhancing MOC strength in addition to auditory training might emerge as a strategy to treat dyslexic children. In this context, drugs that enhance $\alpha 9 \alpha 10 \mathrm{nAChR}$ activity might be of therapeutic benefit.

\section{Targeting $\alpha 9 \alpha 10 \mathrm{nAChRs}$}

The evidence that nAChRs play a role in a number of different neural functions and disorders has given impetus to the search for drugs that selectively affect different receptor subtypes. However, the recent findings indicating that native receptors are much more heterogeneous than previously thought [116], has hampered the development of receptor-specific compounds [117]. This difficulty is most likely overcome in the case of $\alpha 9$ and $\alpha 10$-containing nAChRs, since these subunits appear only to assemble with each other and not with any of the other nAChR subunits [37,47].

Nicotinic receptor ligands can be classified into three main classes: a) agonists, b) antagonists, and 3) allosteric modulators, which may stimulate or inhibit nAChR function by binding to regulatory sites other than ACh binding sites [117,118]. As discussed above, the design of $\alpha 9 \alpha 10$ selective agonists would be beneficial in the case of NIHL and as an adjuvant in auditory training of dyslexic children. However, very few compounds have been reported as agonists of $\alpha 9 \alpha 10$ receptors. Most classical nAChR agonists, such as nicotine, cytisine and epibatidine are antagonists of this receptor subtype [41]. Thus, positive allosteric modulators emerge as good candidates to enhance receptor activity. Moreover, although nicotinic agonists have shown some beneficial effects in treatment of central nervous system disorders, chronic treatment of humans with such compounds has not been thoroughly characterized and may provide suboptimal benefit because of sustained activation and/or desensitization of the target receptor $[119,120]$. A different approach would be to administer a nicotinic receptor positive allosteric modulator that can reinforce the endogenous cholinergic neurotransmission without directly stimulating the target receptors [121]. Several positive allosteric modulators have been described in the case of $\alpha 7 \mathrm{nAChR}$ [122]. In particular, PNU-120596 not only increases maximal amplitude and potency of ACh-evoked $\alpha 7 \mathrm{nAChR}$ current by several fold, but also almost suppresses desensitization [123]. These characteristics are ideal for a compound targeting $\alpha 9 \alpha 10 \mathrm{nAChRs}$ with the aim of preventing cochlear damage produced by intense noise, since they mimic the effects rendered by the leucine for threonine mutation used to generate the $\alpha 9$ knockin mouse with enhanced resistance to NIHL [25]. The fact that the store active compound ryanodine potentiates $\alpha 9 \alpha 10$-mediated ACh-responses [124], opens a possible avenue for the design of positive allosteric modulators of this receptor subtype.

Finally, if blockade of $\alpha 9 \alpha 10 \mathrm{nAChRs}$ would eventually result in a valid strategy to alleviate tinnitus, a wide variety of compounds could be designed. $\alpha 9 \alpha 10 \mathrm{nAChRs}$ are not only blocked by nicotinic and muscarinic receptor antagonists [37,41,47], but also by compounds that block other members of the family of Cys-loop receptors [40,125]. Thus, compounds like tropisetron and ondansetron that are already used in clinical settings for other conditions and which have high potency on $\alpha 9 \alpha 10$ receptors [125], would be likely first candidates. 


\section{Conclusions}

Much has been learned over the last 60 years concerning the properties and function of the efferent system to the cochlea, beginning with its first description [4], the characterization of the effects of $\mathrm{ACh}$ on isolated hair cells $[32,34]$, to the cloning of the atypical cholinergic receptor of hair cells $[37,47]$. The following years will probably witness the design of hair cell nAChR-based therapies. This most likely will include drugs to prevent NIHL, to alleviate tinnitus and to treat auditory processing disorders.

\section{Acknowledgments}

Financial Support: ABE, EK and PAF are supported by the National Institutes of Deafness and other Communication Disorders (NIDCD) Grant R01DC001508. ABE is supported by an International Research Scholar Grant from the Howard Hughes Medical Institute, the Tinnitus Research Initiative, Research Grants from ANPCyT (Argentina) and the University of Buenos Aires (Argentina). EK is supported by Research Grants from the University of Buenos Aires (Argentina) and CONICET (Argentina).

\section{References}

1. Hudspeth A. How hearing happens. Neuron 1997;19:947-50. [PubMed: 9390507]

2. Guinan, JJ. Physiology of olivocochlear efferents. In: Dallos; Popper; Fay, editors. The Cochlea. New York: Springer-Verlag; 1996. p. 435-502.

3. Guinan JJ, Warr WB, Norris BE. Differential olivocochlear projections from lateral vs medial zones of the superior olivary complex. J Comp Neurol 1983;221:358-70. [PubMed: 6655089]

4. Rasmussen GL. The olivary peduncle and other fiber projections of the superior olivary complex. J Comp Neurol 1946;84:141-219.

5. Warr, W. Organization of olivocochlear efferent sytems in mammals. In: Douglas, W.; Popper, A.; Fay, R., editors. The mammalian auditory pathway: Neuroanatomy. New York: Springler-Verlag; 1992. p. 410-48.

6. Dallos P. Cochlear amplification, outer hair cells and prestin. Curr Opin Neurobiol 2008;18:370-6. [PubMed: 18809494]

7. Hudspeth AJ. Making an effort to listen: mechanical amplification in the ear. Neuron 2008;59:53045. [PubMed: 18760690]

8. Chan DK, Hudspeth AJ. Ca2+ current-driven nonlinear amplification by the mammalian cochlea in vitro. Nat Neurosci 2005;8:149-55. [PubMed: 15643426]

9. Jia S, He DZ. Motility-associated hair-bundle motion in mammalian outer hair cells. Nat Neurosci 2005;8:1028-34. [PubMed: 16041370]

10. Kennedy HJ, Crawford AC, Fettiplace R. Force generation by mammalian hair bundles supports a role in cochlear amplification. Nature 2005;433:880-3. [PubMed: 15696193]

11. Brownell W, Bader C, Bertrand D, de Ribaupierre Y. Evoked mechanical responses of isolated cochlear hair cells. Science 1985;227:194-6. [PubMed: 3966153]

12. Zheng J, Shen W, He DZ, Long KB, Madison LD, Dallos P. Prestin is the motor protein of cochlear outer hair cells. Nature 2000;405:149-55. [PubMed: 10821263]

13. Mount DB, Romero MF. The SLC26 gene family of multifunctional anion exchangers. Pflugers Arch 2004;447:710-21. [PubMed: 12759755]

14. Franchini LF, Elgoyhen AB. Adaptive evolution in mammalian proteins involved in cochlear outer hair cell electromotility. Mol Phylogenet Evol 2006;41:622-35. [PubMed: 16854604]

15. Fuchs P. Synaptic transmission at vertebrate hair cells. Current Opinion in Neurobiol 1996;6:514-9.

16. Dolan DF, Nuttall AL. Masked cochlear whole-nerve response intensity functions altered by electrical stimulation of the crossed olivocochlear bundle. J Acoust Soc Am 1988;83:1081-6. [PubMed: 3356813]

17. Kawase T, Delgutte B, Liberman MC. Antimasking effects of the olivocochlear reflex. II. Enhancement of auditory-nerve response to masked tones. J Neurophysiol 1993;70:2533-49. [PubMed: 8120597] 
18. Winslow RL, Sachs MB. Single-tone intensity discrimination based on auditory-nerve rate responses in backgrounds of quiet, noise, and with stimulation of the crossed olivocochlear bundle. Hear Res 1988;35:165-89. [PubMed: 3198509]

19. Delano PH, Elgueda D, Hamame CM, Robles L. Selective attention to visual stimuli reduces cochlear sensitivity in chinchillas. J Neurosci 2007;27:4146-53. [PubMed: 17428992]

20. Oatman LC. Effects of visual attention on the intensity of auditory evoked potentials. Exp Neurol 1976;51:41-53. [PubMed: 1261642]

21. Liberman MC. The olivocochlear efferent bundle and susceptibility of the inner ear to acoustic injury. J Neurophysiol 1991;65:123-32. [PubMed: 1999726]

22. Maison SF, Liberman MC. Predicting vulnerability to acoustic injury with a noninvasive assay of olivocochlear reflex strength. J Neurosci 2000;20:4701-7. [PubMed: 10844039]

23. Maison SF, Luebke AE, Liberman MC, Zuo J. Efferent protection from acoustic injury is mediated via alpha9 nicotinic acetylcholine receptors on outer hair cells. J Neurosci 2002;22:10838-46. [PubMed: 12486177]

24. Rajan R. Electrical stimulation of the inferior colliculus at low rates protects the cochlea from auditory desensitization. Brain Res 1990;506:192-204. [PubMed: 1967964]

25. Taranda J, Maison SF, Ballestero JA, Katz E, Savino J, Vetter DE, et al. A point mutation in the hair cell nicotinic cholinergic receptor prolongs cochlear inhibition and enhances noise protection. PLoS Biol 2009;7:e18. [PubMed: 19166271]

26. Blanchet C, Erostegui C, Sugasawa M, Dulon D. Acetylcholine-induced potassium current of guinea pig outer hair cells: its dependence on a calcium influx through nicotinic-like receptors. J Neurosci 1996;16:2574-84. [PubMed: 8786433]

27. Chen C, LeBlanc C, Bobbin R. Differences in cholinergic responses from outer hair cells of rat and guinea pig. Hearing Research 1996;98:9-17. [PubMed: 8880176]

28. Doi T, Ohmori H. Acetylcholine increases intracellular Ca2+ concetration and hyperpolarizes the guinea-pig outer hair cell. Hearing Res 1993;67:179-88.

29. Dulon D, Lenoir M. Cholinergic responses in developing outer hair cells of the rat cochlea. European J Neurosci 1996;8:1945-52. [PubMed: 8921285]

30. Erostegui C, Norris CH, Bobbin RP. In vitro characterization of a cholinergic receptor on outer hair cells. Hearing Res 1994;74:135-47.

31. Evans M. Acetylcholine activates two currents in guinea-pig outer hair cells. J Physiol 1996;491:56378. [PubMed: 8866879]

32. Fuchs PA, Murrow BW. A novel cholinergic receptor mediates inhibition of chick cochlear hair cells. Proc R Soc Lond B 1992;248:35-40.

33. Fuchs PA, Murrow BW. Cholinergic inhibition of short (outer) hair cells of the chick's cochlea. J Neurosci 1992;12:800-9. [PubMed: 1545240]

34. Housley GD, Ashmore JF. Direct measurement of the action of acetylcholine on isolated outer hair cells of the guinea pig cochlea. Proc R Soc Lond B 1991;244:161-7.

35. Dulon D, Luo L, Zhang C, Ryan AF. Expression of small-conductance calcium-activated potassium channels (SK) in outer hair cells of the rat cochlea. Eur J Neurosci 1998;10:907-15. [PubMed: 9753158]

36. Oliver D, Klocker N, Schuck J, Baukrowitz T, Ruppersberg JP, Fakler B. Gating of Ca2+-activated $\mathrm{K}+$ channels controls fast inhibitory synaptic transmission at auditory outer hair cells. Neuron 2000;26:595-601. [PubMed: 10896156]

37. Elgoyhen AB, Johnson DS, Boulter J, Vetter DE, Heinemann S. $\alpha 9$ : an acetylcholine receptor with novel pharmacological properties expressed in rat cochlear hair cells. Cell 1994;79:705-15. [PubMed: 7954834]

38. Vetter D, Lieberman M, Mann J, Barhanin J, Boulter J, Brown M, et al. Role of $\alpha 9$ nicotinic ACh receptor subunits in the development and function of cochlear efferent innervation. Neuron 1999;23:93-103. [PubMed: 10402196]

39. Katz E, Verbitsky M, Rothlin C, Vetter D, Heinemann S, Elgoyhen A. High calcium permeability and calcium block of the $\alpha 9$ nicotinic acetylcholine receptor. Hearing Res 2000;141:117-28. 
40. Rothlin C, Verbitsky M, Katz E, Elgoyhen A. The $\alpha 9$ nicotinic acetylcholine receptor shares pharmacological properties with type A $\gamma$-aminobutyric acid, glycine and type 3 serotonin receptors. Molec Pharmacol 1999;55:248-54. [PubMed: 9927615]

41. Verbitsky M, Rothlin C, Katz E, Elgoyhen AB. Mixed nicotinic-muscarinic properties of the a9 nicotinic cholinergic receptor. Neuropharmacology 2000;39:2515-24. [PubMed: 11044723]

42. Glowatzki E, Wild K, Brandle U, Fakler G, Fakler B, Zenner HP, et al. Cell-specific expression of the alpha $9 \mathrm{n}$-ACh receptor subunit in auditory hair cells revealed by single-cell RT-PCR. Proc R Soc Lond B 1995;262:141-7.

43. Morley B, Li H, Hiel H, Drescher D, Elgoyhen AB. Identification of the subunits of the nicotinic cholinergic receptors in the rat cochlea using RT-PCR and in situ hybridization. Molec Brain Res 1998;53:78-87. [PubMed: 9473597]

44. McNiven AI, Yuhas WA, Fuchs PA. Ionic dependence and agonist preference of an acetylcholine receptor in hair cells. Auditory Neurosci 1996;2:63-77.

45. Le Novere N, Changeux J. Molecular evolution of the nicotinic acetylcholine receptor: an example of multigene family in excitable cells. J Molec Evol 1995;40:155-72. [PubMed: 7699721]

46. Le Novere N, Corringer PJ, Changeux JP. The diversity of subunit composition in nAChRs: evolutionary origins, physiologic and pharmacologic consequences. J Neurobiol 2002;53:447-56. [PubMed: 12436412]

47. Elgoyhen AB, Vetter D, Katz E, Rothlin C, Heinemann S, Boulter J. Alpha 10: A determinant of nicotinic cholinergic receptor function in mammalian vestibular and cochlear mechanosensory hair cells. Proc Natl Acad Sci USA 2001;98:3501-6. [PubMed: 11248107]

48. Lustig LR, Peng H, Hiel H, Yamamoto T, Fuchs P. Molecular cloning and mapping of the human nicotinic acetylcholine receptor $\alpha 10$ (CHRNA10). Genomics 2001;73:272-83. [PubMed: 11350119]

49. Sgard F, Charpentier E, Bertrand S, Walker N, Caput D, Graham D, et al. A novel human nicotinic receptor subunit, $\alpha 10$, that confers functionality to the $\alpha 9$-subunit. Molec Pharmacol 2002;61:1509. [PubMed: 11752216]

50. Vetter DE, Katz E, Maison SF, Taranda J, Turcan S, Ballestero J, et al. The alpha10 nicotinic acetylcholine receptor subunit is required for normal synaptic function and integrity of the olivocochlear system. Proc Natl Acad Sci U S A 2007;104:20594-9. [PubMed: 18077337]

51. Plazas PV, Katz E, Gomez-Casati ME, Bouzat C, Elgoyhen AB. Stoichiometry of the $\alpha 9 \alpha 10$ Nicotinic Cholinergic Receptor. J Neurosci 2005;25:10905-12. [PubMed: 16306403]

52. Vio MM, Holme RH. Hearing loss and tinnitus: 250 million people and a US $\$ 10$ billion potential market. Drug Discov Today 2005;10:1263-5. [PubMed: 16214667]

53. Cohen SM, Labadie RF, Haynes DS. Primary care approach to hearing loss: the hidden disability. Ear Nose Throat J 2005;84:26, 9-31, 44. [PubMed: 15742769]

54. Mohr PE, Feldman JJ, Dunbar JL, McConkey-Robbins A, Niparko JK, Rittenhouse RK, et al. The societal costs of severe to profound hearing loss in the United States. Int J Technol Assess Health Care 2000;16:1120-35. [PubMed: 11155832]

55. Cryns K, Van Camp G. Deafness genes and their diagnostic applications. Audiol Neurootol 2004;9:222. [PubMed: 14676470]

56. Vrijens K, Van Laer L, Van Camp G. Human hereditary hearing impairment: mouse models can help to solve the puzzle. Hum Genet 2008;124:325-48. [PubMed: 18784944]

57. Pujol R, Carlier E. Cochlear synaptogenesis after sectioning the efferent bundle. Brain Res 1982;255:151-4. [PubMed: 7055717]

58. Walsh, E.; McGee, J. Does activity in the olivocochlear bundle affect development of the auditory periphery?. In: Lewis, E.; Long, G.; Lyon, R.; Narins, P.; Steele, C.; Hecht-Poinar, E., editors. Diversity in auditory mechanics. Singapore: World Scientific; 1997. p. 376-85.

59. Walsh E, McGee J, McFadden S, Liberman M. Long-term effects of sectioning the olivocochlear bundle in neonatal cats. J Neurosci 1998;18:3859-69. [PubMed: 9570815]

60. Simmons DD. Development of the inner ear efferent system across vertebrate species. J Neurobiol 2002;53:228-50. [PubMed: 12382278]

61. Glowatzki E, Fuchs P. Cholinergic synaptic inhibition of inner hair cells in the neonatal mammalian cochlea. Science 2000;288:2366-8. [PubMed: 10875922] 
62. Katz E, Elgoyhen AB, Gomez-Casati ME, Knipper M, Vetter DE, Fuchs PA, et al. Developmental regulation of nicotinic synapses on cochlear inner hair cells. J Neurosci 2004;24:7814-20. [PubMed: 15356192]

63. Lim DJ. Effects of noise and ototoxic drugs at the cellular level in the cochlea: a review. Am J Otolaryngol 1986;7:73-99. [PubMed: 3515985]

64. Borg E, Canlon B, Engstrom B. Noise-induced hearing loss. Literature review and experiments in rabbits. Morphological and electrophysiological features, exposure parameters and temporal factors, variability and interactions. Scand Audiol Suppl 1995;40:1-147. [PubMed: 7732328]

65. Barney R, Bohnker BK. Hearing thresholds for U.S. Marines: comparison of aviation, combat arms, and other personnel. Aviat Space Environ Med 2006;77:53-6. [PubMed: 16422454]

66. Bohnker BK, Page JC, Rovig GW, Betts LS, Sack DM. Navy Hearing Conservation Program: 1995-1999 retrospective analysis of threshold shifts for age, sex, and officer/enlisted status. Mil Med 2004;169:73-6. [PubMed: 14964507]

67. Rovig GW, Bohnker BK, Page JC. Hearing health risk in a population of aircraft carrier flight deck personnel. Mil Med 2004;169:429-32. [PubMed: 15281670]

68. Neitzel R, Meischke H, Daniell WE, Trabeau M, Somers S, Seixas NS. Development and pilot test of hearing conservation training for construction workers. Am J Ind Med 2008;51:120-9. [PubMed: 18067178]

69. Tak S, Davis RR, Calvert GM. Exposure to hazardous workplace noise and use of hearing protection devices among US workers-NHANES, 1999-2004. Am J Ind Med. 2009epub ahead of print

70. Trabeau M, Neitzel R, Meischke H, Daniell WE, Seixas NS. A comparison of "Train-the-Trainer" and expert training modalities for hearing protection use in construction. Am J Ind Med 2008;51:1307. [PubMed: 18067179]

71. Landen D, Wilkins S, Stephenson M, McWilliams L. Noise exposure and hearing loss among sand and gravel miners. J Occup Environ Hyg 2004;1:532-41. [PubMed: 15238306]

72. Neitzel R, Yost M. Task-based assessment of occupational vibration and noise exposures in forestry workers. AIHA J (Fairfax, Va) 2002;63:617-27.

73. Beckett WS, Chamberlain D, Hallman E, May J, Hwang SA, Gomez M, et al. Hearing conservation for farmers: source apportionment of occupational and environmental factors contributing to hearing loss. J Occup Environ Med 2000;42:806-13. [PubMed: 10953818]

74. Hong OS, Kim MJ. Factors associated with hearing loss among workers of the airline industry in Korea. ORL Head Neck Nurs 2001;19:7-13. [PubMed: 12024523]

75. Jaruchinda P, Thongdeetae T, Panichkul S, Hanchumpol P. Prevalence and an analysis of noise-induced hearing loss in army helicopter pilots and aircraft mechanics. J Med Assoc Thai 2005;88:S232-9. [PubMed: 16862680]

76. Kim J, Park H, Ha E, Jung T, Paik N, Yang S. Combined effects of noise and mixed solvents exposure on the hearing function among workers in the aviation industry. Ind Health 2005;43:567-73. [PubMed: 16100934]

77. Landon P, Breysse P, Chen Y. Noise exposures of rail workers at a North American chemical facility. Am J Ind Med 2005;47:364-9. [PubMed: 15776466]

78. Seshagiri B. Exposure to noise on board locomotives. AIHA J (Fairfax, Va) 2003;64:699-707.

79. Kumar A, Mathur NN, Varghese M, Mohan D, Singh JK, Mahajan P. Effect of tractor driving on hearing loss in farmers in India. Am J Ind Med 2005;47:341-8. [PubMed: 15776468]

80. Solecki L. Characteristics of annual exposure to noise among private farmers on family farms of mixed-production profile. Ann Agric Environ Med 2006;13:113-8. [PubMed: 16841882]

81. Biassoni EC, Serra MR, Richtert U, Joekes S, Yacci MR, Carignani JA, et al. Recreational noise exposure and its effects on the hearing of adolescents. Part II: development of hearing disorders. Int J Audiol 2005;44:74-85. [PubMed: 15913155]

82. Serra MR, Biassoni EC, Richter U, Minoldo G, Franco G, Abraham S, et al. Recreational noise exposure and its effects on the hearing of adolescents. Part I: an interdisciplinary long-term study. Int J Audiol 2005;44:65-73. [PubMed: 15913154]

83. Lynch ED, Kil J. Compounds for the prevention and treatment of noise-induced hearing loss. Drug Discov Today 2005;10:1291-8. [PubMed: 16214673] 
84. Henderson D, Bielefeld EC, Harris KC, Hu BH. The role of oxidative stress in noise-induced hearing loss. Ear Hear 2006;27:1-19. [PubMed: 16446561]

85. Kopke RD, Jackson RL, Coleman JK, Liu J, Bielefeld EC, Balough BJ. NAC for noise: from the bench top to the clinic. Hear Res 2007;226:114-25. [PubMed: 17184943]

86. Wang J, Ruel J, Ladrech S, Bonny C, van de Water TR, Puel JL. Inhibition of the c-Jun N-terminal kinase-mediated mitochondrial cell death pathway restores auditory function in sound-exposed animals. Mol Pharmacol 2007;71:654-66. [PubMed: 17132689]

87. Kil J, Pierce C, Tran H, Gu R, Lynch ED. Ebselen treatment reduces noise induced hearing loss via the mimicry and induction of glutathione peroxidase. Hear Res 2007;226:44-51. [PubMed: 17030476]

88. Chen GD, Kong J, Reinhard K, Fechter LD. NMDA receptor blockage protects against permanent noise-induced hearing loss but not its potentiation by carbon monoxide. Hear Res 2001;154:108-15. [PubMed: 11423221]

89. Duan M, Chen Z, Qiu J, Ulfendahl M, Laurell G, Borg E, et al. Low-dose, long-term caroverine administration attenuates impulse noise-induced hearing loss in the rat. Acta Otolaryngol 2006;126:1140-7. [PubMed: 17050305]

90. Reiter ER, Liberman MC. Efferent-mediated protection from acoustic overexposure: relation to slow effects of olivocochlear stimulation. J Neurophysiol 1995;73:506-14. [PubMed: 7760114]

91. Kujawa SG, Liberman MC. Conditioning-related protection from acoustic injury: effects of chronic deefferentation and sham surgery. J Neurophysiol 1997;78:3095-106. [PubMed: 9405529]

92. Handrock M, Zeisberg J. The influence of the effect system on adaptation, temporary and permanent threshold shift. Arch Otorhinolaryngol 1982;234:191-5. [PubMed: 7092707]

93. Eggermont JJ. Role of auditory cortex in noise- and drug-induced tinnitus. Am J Audiol 2008;17:S162-9. [PubMed: 18978202]

94. Moller AR. Tinnitus: presence and future. Prog Brain Res 2007;166:3-16. [PubMed: 17956767]

95. Tyler R, Coelho C, Tao P, Ji H, Noble W, Gehringer A, et al. Identifying tinnitus subgroups with cluster analysis. Am J Audiol 2008;17:S176-84. [PubMed: 19056922]

96. Mount C, Downton C. Alzheimer disease: progress or profit? Nat Med 2006;12:780-4. [PubMed: 16829947]

97. Rammes G, Schierloh A. Neramexane (merz pharmaceuticals/forest laboratories). IDrugs 2006;9:128-35. [PubMed: 16523403]

98. Plazas PV, Savino J, Kracun S, Gomez-Casati ME, Katz E, Parsons CG, et al. Inhibition of the alpha9alpha10 nicotinic cholinergic receptor by neramexane, an open channel blocker of N-methylD-aspartate receptors. Eur J Pharmacol 2007;566:11-9. [PubMed: 17466293]

99. Eggermont JJ. Tinnitus: neurobiological substrates. Drug Discov Today 2005;10:1283-90. [PubMed: 16214672]

100. Van de Heyning P, Vermeire K, Diebl M, Nopp P, Anderson I, De Ridder D. Incapacitating unilateral tinnitus in single-sided deafness treated by cochlear implantation. Ann Otol Rhinol Laryngol 2008;117:645-52. [PubMed: 18834065]

101. Mody M, Wehner DT, Ahlfors SP. Auditory word perception in sentence context in reading-disabled children. Neuroreport 2008;19:1567-71. [PubMed: 18815588]

102. Demonet JF, Taylor MJ, Chaix Y. Developmental dyslexia. Lancet 2004;363:1451-60. [PubMed: 15121410]

103. Ramirez J, Mann V. Using auditory-visual speech to probe the basis of noise-impaired consonantvowel perception in dyslexia and auditory neuropathy. J Acoust Soc Am 2005;118:1122-33. [PubMed: 16158666]

104. Sperling AJ, Lu ZL, Manis FR, Seidenberg MS. Deficits in perceptual noise exclusion in developmental dyslexia. Nat Neurosci 2005;8:862-3. [PubMed: 15924138]

105. Kawase T, Liberman MC. Antimasking effects of the olivocochlear reflex. I. Enhancement of compound action potentials to masked tones. J Neurophysiol 1993;70:2519-32. [PubMed: 8120596]

106. Micheyl C, Carbonnel O, Collet L. Medial olivocochlear system and loudness adaptation: differences between musicians and non-musicians. Brain Cogn 1995;29:127-36. [PubMed: 8573328] 
107. Micheyl C, Collet L. Involvement of the olivocochlear bundle in the detection of tones in noise. $\mathrm{J}$ Acoust Soc Am 1996;99:1604-10. [PubMed: 8819856]

108. Micheyl C, Khalfa S, Perrot X, Collet L. Difference in cochlear efferent activity between musicians and non-musicians. Neuroreport 1997;8:1047-50. [PubMed: 9141090]

109. Micheyl C, Perrot X, Collet L. Relationship between auditory intensity discrimination in noise and olivocochlear efferent system activity in humans. Behav Neurosci 1997;111:801-7. [PubMed: 9267657]

110. Giraud AL, Garnier S, Micheyl C, Lina G, Chays A, Chery-Croze S. Auditory efferents involved in speech-in-noise intelligibility. Neuroreport 1997;8:1779-83. [PubMed: 9189932]

111. Kumar UA, Vanaja CS. Functioning of olivocochlear bundle and speech perception in noise. Ear Hear 2004;25:142-6. [PubMed: 15064659]

112. Veuillet E, Bazin F, Collet L. Objective evidence of peripheral auditory disorders in learningimpaired children. J Audiol Med 1999;8:18-29.

113. Brashears SM, Morlet TG, Berlin CI, Hood LJ. Olivocochlear efferent suppression in classical musicians. J Am Acad Audiol 2003;14:314-24. [PubMed: 14552425]

114. Veuillet E, Magnan A, Ecalle J, Thai-Van H, Collet L. Auditory processing disorder in children with reading disabilities: effect of audiovisual training. Brain 2007;130:2915-28. [PubMed: 17921181]

115. de Boer J, Thornton AR. Neural correlates of perceptual learning in the auditory brainstem: efferent activity predicts and reflects improvement at a speech-in-noise discrimination task. J Neurosci 2008;28:4929-37. [PubMed: 18463246]

116. Lindstrom JM. Nicotinic acetylcholine receptors of muscles and nerves: comparison of their structures, functional roles, and vulnerability to pathology. Ann N Y Acad Sci 2003;998:41-52. [PubMed: 14592862]

117. Gotti C, Riganti L, Vailati S, Clementi F. Brain neuronal nicotinic receptors as new targets for drug discovery. Curr Pharm Des 2006;12:407-28. [PubMed: 16472136]

118. Hogg RC, Buisson B, Bertrand D. Allosteric modulation of ligand-gated ion channels. Biochem Pharmacol 2005;70:1267-76. [PubMed: 16043127]

119. White HK, Levin ED. Chronic transdermal nicotine patch treatment effects on cognitive performance in age-associated memory impairment. Psychopharmacology (Berl) 2004;171:465-71. [PubMed: 14534771]

120. Smith RC, Singh A, Infante M, Khandat A, Kloos A. Effects of cigarette smoking and nicotine nasal spray on psychiatric symptoms and cognition in schizophrenia. Neuropsychopharmacology 2002;27:479-97. [PubMed: 12225705]

121. Albuquerque EX, Santos MD, Alkondon M, Pereira EF, Maelicke A. Modulation of nicotinic receptor activity in the central nervous system: a novel approach to the treatment of Alzheimer disease. Alzheimer Dis Assoc Disord 2001;15:S19-25. [PubMed: 11669505]

122. Bertrand D, Gopalakrishnan M. Allosteric modulation of nicotinic acetylcholine receptors. Biochem Pharmacol 2007;74:1155-63. [PubMed: 17707779]

123. Hurst RS, Hajos M, Raggenbass M, Wall TM, Higdon NR, Lawson JA, et al. A novel positive allosteric modulator of the alpha7 neuronal nicotinic acetylcholine receptor: in vitro and in vivo characterization. J Neurosci 2005;25:4396-405. [PubMed: 15858066]

124. Zorrilla de San Martin J, Ballestero J, Katz E, Elgoyhen AB, Fuchs PA. Ryanodine is a positive modulator of acetylcholine receptor gating in cochlear hair cells. J Assoc Res Otolaryngol 2007;8:474-83. [PubMed: 17647061]

125. Rothlin CV, Lioudyno MI, Silbering AF, Plazas PV, Casati ME, Katz E, et al. Direct interaction of serotonin type 3 receptor ligands with recombinant and native alpha 9 alpha 10-containing nicotinic cholinergic receptors. Mol Pharmacol 2003;63:1067-74. [PubMed: 12695535]

\section{Abbreviations}

ACh

acetylcholine

Chrna9

Biochem Pharmacol. Author manuscript; available in PMC 2010 October 1. 
gene that codes for the $\alpha 9 \mathrm{nAChR}$ subunit

Chrna10

gene that codes for the $\alpha 10 \mathrm{nAChR}$ subunit

IHCs

inner hair cells

MOC

medial olivocochlear

nAChRs

nicotinic acetylcholine receptors

NIHL

noise-induced hearing loss

OC

olivocochlear

OHCs

outer hair cells 


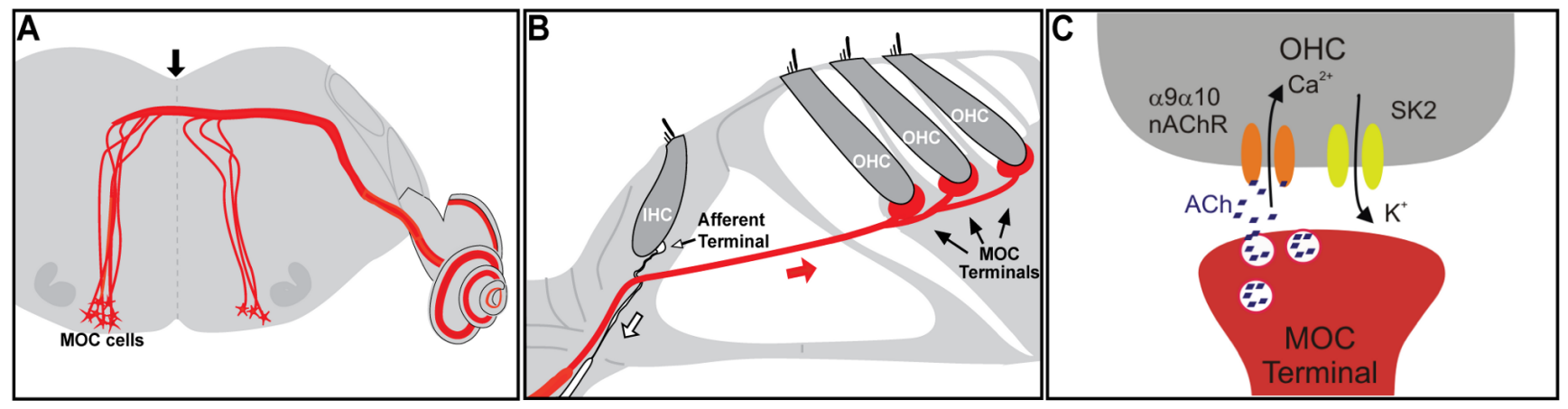

Figure 1.

Schematics showing the central origin (A) and peripheral projections (B) of the MOC fibers and the cholinergic synapse onto OHCs in the mature organ of Corti (C). MOC efferent neurons are located in the superior olivary complex of the brainstem and project to the cochlea, where they make direct synaptic contacts at the base of the OHCs. At this synapse ACh is released. It binds to $\alpha 9 \alpha 10$ receptors present at the OHCs, leading to $\mathrm{Ca}^{2+}$ influx and the subsequent activation of $\mathrm{Ca}^{2+}$-dependent SK2 $\mathrm{K}^{+}$channels and hair cell hyperpolarization. The arrow in $\mathrm{A}$ indicates the place of electrical stimulation to activate the MOC fibers. The white arrow in $\mathrm{B}$, indicates the afferent fibers which bring information from the IHCs to the central nervous system and the red arrow the MOC fibers. For approximately ten days after birth (before the onset of hearing), cholinergic efferents temporarily synapse directly with IHCs and the cholinergic receptors at that synapse are also of the $\alpha 9 \alpha 10$ subtype (not shown). Reproduced from Taranda et al., PLoS Biology, 7(1):e18: 71-83, 2009. 

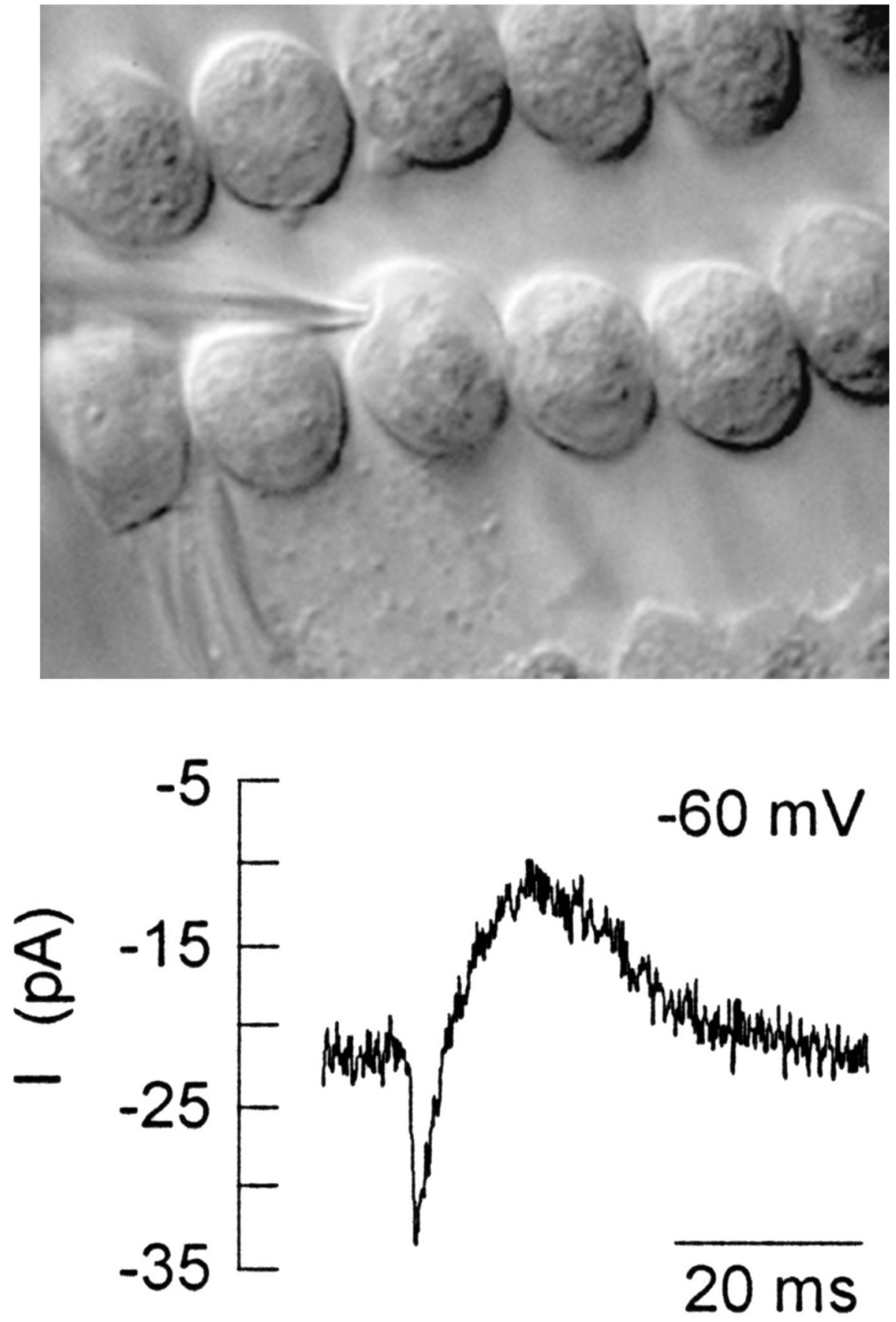

Figure 2.

Whole cell patch clamp used to record efferent synaptic currents from OHCs in the organ of Corti ex vivo. Upper panel shows a patch pipette attached to a first row $\mathrm{OHC}$ in the apical turn of a postnatal day 16 rat cochlea. Lower panel shows the typical biphasic synaptic current (-60 $\mathrm{mV}$ holding potential) produced by spontaneous ACh release from the presynaptic efferent terminal. It has been demonstrated that this biphasic current flow results from the sequential activation of $\alpha 9 \alpha 10$-containing nAChRs, followed by calcium-gated (SK) potassium channels. Micrograph and recording courtesy of M. Lioudyno. 
Table 1

Maximal Sound Pressure Levels (SPLs), durations and sources that can irreversibly damage hearing (The National Institute for Occupational Safety and Health, http://www.cdc.gov/NIOSH/).

\begin{tabular}{lll}
\hline SPL & Duration & Source \\
\hline $140 \mathrm{~dB}$ & $<1 \mathrm{~min}$ & firearms, jet planes \\
$130 \mathrm{~dB}$ & $>1 \mathrm{~min}$ & jackhammers \\
$120 \mathrm{~dB}$ & $>5 \mathrm{~min}$ & amplified car stereo \\
$110 \mathrm{db}$ & $>15 \mathrm{~min}$ & rock concerts, planes \\
$100 \mathrm{~dB}$ & $>1 \mathrm{hr}$ & woodshops, chainsaws \\
$90 \mathrm{~dB}$ & $>4 \mathrm{hr}$ & motorcycles, lawnmowers \\
$85 \mathrm{~dB}$ & $>8 \mathrm{hr}$ & interior plane cabins \\
\hline
\end{tabular}

